\title{
GAMBARAN KARAKTERISTIK WANITA YANG MENGALAMI KANKER SERVIKS DI RUMAH SAKIT UMUM DAERAH (RSUD) PANEMBAHAN SENOPATI BANTUL YOGYAKARTA
}

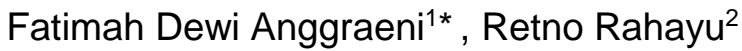

${ }_{1,2}$ Program Studi Kebidanan Stikes Jenderal Achmad Yani Yogyakarta, Jl. Ringroad Barat Ambarketawang, Gamping, Sleman.Telp.(02744342000), email: dewianggraeni303@gmail.com

\begin{abstract}
Background : Cervical cancer is still becoming the most prevalent diseases in Indonesia. Health Department of Indonesia in 2012 recorded that the predicted incidence and mortality rate which caused by cervical cancer were 13.2 million of lifes. Factors that affecting cervical cancer are age, education, job, parity, and hormonal contracepcy. This statement is supported by the Hospital Information System (HIS) data in the year of 2013 which showed that there were 130 cases of cervical cancer in Yogyakarta (DIY). The opreliminary study obtained that in 2015 there were 50 persons of cervical cancer sufferer in Panembahan Senopati Public Hospital, which were consist of 40 outpatient cases and 10 inpatient cases.

Aim : This study aimed to know the characteristics of mothers who encounter cervical cancer.

Research Methods : This research was a descriptive quantitative research. The sampling technique used in this research was total sampling technique. The samples were 50 respondents with frequency distribution that obtained by using secondary data and checklist methods.

Results : Most of mothers who encounter cervical cancer in Panembahan Senopati public hospital Bantul Yogyakarta that aged $>35$ years old were as many as 34 respondents $(68.0 \%)$, as many as 26 respondents (52.0\%) were high school educated or graduated, as many as 18 repondents (36.05) were statused as a farmer, as many as 18 repondents (36.0\%) were primiparas and grandemulti parity, and as many as 29 respondents $(58.0 \%)$ were using hormonal contracepcy.

Conclusion : Mothers who encounter cervical cancer in Panembahan Senopati public hospital Bantul Yogyakarta that aged $>35$ years old were: high school educated or graduated, farmers, primiparas and grandmultiparas, and using hormonal contracepcy.
\end{abstract}

Keywords : Characteristic, Cervical cancer.

\section{PENDAHULUAN}

Angka kematian Ibu adalah salah satu indikator Millennium Development Goals (MDG's) yang belum selesai dan perlu dilanjutkan pada agenda pasca 2015 yaitu pembangunan berkelanjutan atau Suistainable Development Goals (SDGs). Salah satu target SDGs pada tahun 2030 adalah mengurangi angka kematian ibu hingga di bawah 70 per 100.000 kelahiran hidup. Kanker serviks merupakan keganasan yang tumbuh pada awalnya di daerah SSK (Sambungan Skuamo Kolumner) dari serviks. ${ }^{1}$

Kanker serviks merupakan pembunuh wanita kedua di dunia setelah kanker payudara. $^{2}$ Wanita yang mengidap kanker serviks seluruh dunia sekitar 471.000 dengan angka kematian 215.000. Sementara itu, di negara berkembang kanker serviks menempati urutan teratas sebagai penyebab kematian akibat kanker di usia produktif. Hampir $80 \%$ kasus berada di negara berkembang. ${ }^{3}$ 
Faktor risiko kanker serviks adalah umur, paritas, pekerjaan, wanita yang berusia 35-50 tahun dan masih aktif melakukan hubungan seksual, kanker serviks cenderung lebih banyak terjadi pada wanita yang berpendidikan rendah. Pada pekerja wanita kasar, seperti buruh, petani memperlihatkan 4 kali lebih mungkin terkena kanker serviks dibandingkan wanita pekerja ringan atau bekerja di kantor. Penderita kanker serviks $7,9 \%$ adalah multipara dan $51 \%$ pada nullipara, di mana bila persalinan pervaginam banyak maka kanker serviks cenderung timbul. ${ }^{4}$ Penggunaan kontrasepsi hormon dalam jangka waktu yang lama juga meningkatkan risiko terjadinya kanker serviks. $^{5}$ Wanita-wanita yang tingkat ekonominya rendah risiko terkena kanker serviks tinggi karena mereka tidak mempunyai akses pada pelayanan kesehatan yang memadai, untuk melakukan Pap Smear dan IVA test secara rutin. ${ }^{6}$

Data SIRS (Sistem Informasi Rumah sakit) tahun 2013 yang diperoleh dari Dinas Kesehatan DIY, menyatakan bahwa kabupaten Bantul peringkat pertama dengan kasus kanker serviks yaitu 74 kasus. Studi pendahuluan yang dilakukan pada tanggal 10 Juni 2016 di RSUD Panembahan Senopati Bantul didapatkan penderita kanker serviks tahun 2015 sebanyak 50 orang yang menderita kanker serviks. Untuk rawat jalan terdapat 40 kasus dan rawat inap terdapat 10 kasus.

\section{BAHAN DAN CARA PENELITIAN}

Jenis penelitian ini adalah merupakan penelitian deskriptif kuantitatif. Populasi dalam penelitian adalah seluruh penderita kanker serviks di RSUD Panembahan Senopati Bantul Yogyakarta pada tahun 2015. berjumlah 50 orang diambil dengan total sampling yaitu semua populasi digunakan sebagai objek penelitian. Analisis data yang digunakan yaitu menggunakan analisis multivariat. Dalam penelitian ini, peneliti menggambarkan tentang karakteristik wanita yang mengalami Kanker serviks di RSUD Panembahan Senopati Bantul meliputi umur, pendidikan, pekerjaan, paritas, dan penggunaan kontrasepsi hormonal.

\section{HASIL DAN PEMBAHASAN}

Tabel 1. Distribusi Frekuensi Responden Berdasarkan Umur di RSUD Panembahan Senopati Bantul

\begin{tabular}{lcc}
\hline \multicolumn{1}{c}{ Umur } & $\mathbf{f}$ & $\%$ \\
\hline $20-35$ tahun & 16 & 32,0 \\
$>35$ tahun & 34 & 68,0 \\
\hline Jumlah & 50 & 100
\end{tabular}

Tabel 1 menunjukkan bahwa sebagian besar responden penderita kanker serviks pada usia $>35$ tahun sebanyak 34 responden (68,0\%). Umur sangat berpengaruh terhadap kejadian kanker serviks khususnya di Negara Indonesia dibandingkan dengan negara berkembang lainnya. Kebanyakan ditemukan pada usia produktif adalah antara umur 20-35 tahun. ${ }^{7}$ Wanita yang rawan menderita kanker serviks adalah wanita yang berusia $35-50$ 
tahun dan masih berhubungan seksual, hal ini dikarenakan semakin lemahnya sistem imunitas tubuh meskipun sebenarnya perkembangan sel kanker telah dimulai sejak 10-15 tahun sebelumnya. ${ }^{8}$ Penelitian ini sejalan dengan penelitian yang dilakukan oleh Sulistiyowati yaitu ada hubungan yang bermakna antara tingkat pendidikan dengan kanker serviks. ${ }^{9}$

\section{Tabel 2. Distribusi Frekuensi Responden Berdasarkan Pendidikan di RSUD Panembahan Senopati Bantul}

\begin{tabular}{lcc}
\hline \multicolumn{1}{c}{ Pendidikan } & $\mathbf{f}$ & $\%$ \\
\hline Dasar & 24 & 48,0 \\
Menengah & 26 & 52,0 \\
Tinggi & 0 & 0 \\
\hline Jumlah & 50 & 100 \\
\hline
\end{tabular}

Tabel 2 menunjukkan bahwa sebagian besar responden penderita kanker serviks berpendidikan menengah sebanyak 26 responden (52,0\%). Wanita yang berpendidikan tinggi akan memikirkan faktor risiko dalam bertindak/berperilaku sehingga akan lebih bersikap hati-hati, teratur, dan jujur dalam berperilaku. ${ }^{10}$ Kanker serviks cenderung lebih banyak terjadi pada wanita yang berpendidikan rendah dibandingkan dengan wanita yang berpendidikan tinggi. Tinggi rendahnya pendidikan berkaitan dengan tingkat sosial ekonomi, kehidupan seksual dan kebersihan diri. Penderita kanker serviks yang berpendidikan rendah merupakan faktor risiko yang memengaruhi kanker serviks. ${ }^{11}$ Hasil penelitian ini sejalan dengan penelitian yang dilakukan oleh Anna yaitu ada hubungan yang bermakna antara tingkat pendidikan dengan kanker serviks. Hasil penelitian kanker serviks sebagian besar berpendidikan Menengah dan kurang memperhatikan keadaan kesehatan mereka sendiri. ${ }^{12}$

$\begin{aligned} & \text { Tabel 3. Distribusi Frekuensi Responden } \\
& \text { Berdasarkan Pekerjaan di RSUD } \\
& \text { Panembahan Senopati Bantul }\end{aligned}$
\begin{tabular}{lcc}
\hline Pekerjaan & $\%$ \\
\hline $\begin{array}{l}\text { Tidak } \\
\text { bekerja }\end{array}$ & 12 & 24,0 \\
PNS & 1 & 2,0 \\
Buruh & 15 & 30,0 \\
Petani & 18 & 36,0 \\
Pedagang & 3 & 6,0 \\
Swasta & 1 & 2,0 \\
\hline Total & 50 & 100
\end{tabular}

Tabel 3 menunjukkan bahwa sebagian besar responden penderita kanker serviks memiliki pekerjaan sebagai petani yaitu sebanyak 18 responden (36,0\%). Bagi para wanita pekerja kasar, seperti buruh, petani memperlihatkan 4 kali lebih mungkin terkena kanker serviks dibandingkan wanita pekerja ringan atau bekerja di kantor. Dua kejadian memperlihatkan adanya hubungan antara kanker serviks dengan pekerjaan. ${ }^{13}$ Pekerjaan akan berindentik dengan ekonomi. Wanita dengan pendapatan rendah tidak 
memiliki akses siap untuk layanan perawatan kesehatan yang memadai, termasuk tes Pap. ${ }^{14}$ Wanita di kelas sosial ekonomi yang paling rendah memiliki faktor risiko lima kali lebih besar daripada wanita di kelas yang paling tinggi. ${ }^{15}$

Tabel 4 Distribusi Frekuensi Responden Berdasarkan Paritas di RSUD Panembahan Senopati Bantul

\begin{tabular}{ccc}
\hline Paritas & $\mathbf{f}$ & $\%$ \\
\hline Nullipara & 1 & 2,0 \\
Primipara & 13 & 26,0 \\
Multipara & 18 & 36,0 \\
Grandemulti & 18 & 36,0 \\
\hline Total & 50 & 100 \\
\hline
\end{tabular}

Tabel 4 menunjukkan bahwa sebagian besar responden penderita kanker serviks memiliki paritas sebanyak multipara dan grandemultipara sebanyak 18 responden $(36,0 \%)$. Pada umumnya kanker serviks terjadi pada wanita yang sering melahirkan 35 kali. Pada paritas tinggi rawan terjadi kanker serviks dimana bila persalinan banyak maka kanker serviks cenderung akan timbul. ${ }^{4}$ Hasil penelitian ini sesuai dengan yang dilakukan Lasut yaitu paritas berkaitan dengan jumlah yang diinginkan, bahwa makin tinggi paritas maka insiden kanker serviks makin tinggi, tingginya paritas bukan merupakan penyebab tetapi sebagai salah satu faktor risiko untuk terinfeksi virus HPV yang berisiko tinggi. ${ }^{16}$

Tabel 5. menunjukkan bahwa sebagian besar responden pederita kanker serviks menggunakan kontrasepsi hormonal.
Tabel 5. Ditribusi Frekuensi Responden Berdasarkan Penggunaan Kontrasepsi Hormonal di RSUD Panembahan Senopati Bantul

\begin{tabular}{ccc}
\hline $\begin{array}{c}\text { Kontrasepsi } \\
\text { hormonal }\end{array}$ & $\mathbf{f}$ & $\%$ \\
\hline Ya & 29 & 58,0 \\
Tidak & 21 & 42,0 \\
\hline Total & 50 & 100 \\
\hline
\end{tabular}

Penggunaan kontrasepsi hormon dalam jangka waktu yang lama dapat meningkatkan risiko terjadinya kanker serviks. ${ }^{5}$ Pemakaian kontrasepsi hormon dalam jangka waktu lama lebih dari 4 tahun dapat meningkatkan risiko terkena kanker serviks 1,5-2,5 kali. Pil kontrasepsi oral diduga akan menyebabkan defisieni asam folat yang mengurangi metabolisme mutagen sedangkan estrogen kemungkinan menjadi salah satu kofaktor yang membuat replikasi DNA HPV. ${ }^{13}$ Analisis data oleh International Agency for Research on Cancer (IARC) menemukan bahwa ada peningkatan risiko kanker serviks dengan penggunaan kontrasepsi oral dan risiko berkurang ketika obat di hentikan. Dimana ditemukan peningkatan resiko $4 \mathrm{x}$ lebih besar pada pengguna kontrasepsi oral lebih dari 5 tahun. ${ }^{17}$ 


\section{KESIMPULAN}

Distribusi frekuensi lbu yang mengalami kanker serviks di Panembahan Senopati Bantul sebagian besar berusia $>35$ tahun sebanyak 34 responden $(68,0 \%)$. Distribusi frekuensi ibu yang mengalami kanker serviks di Panembahan Senopati Bantul sebagian besar berpendidikan Menengah yaitu SMA dan SMK sebanyak 26 responden (52,0\%). Distribusi frekuensi ibu yang mengalami kanker serviks di Panembahan Senopati Bantul sebagian besar memiliki status berkerja sebagai petani sebanyak 18 responden (36,0\%). Distribusi frekuensi ibu yang mengalami kanker serviks di Panembahan Senopati Bantul sebagian besar memiliki status paritas multipara dan grandemultipara sebanyak 18 responden (36,0\%). Distribusi frekuensi ibu yang mengalami kanker serviks di Panemahan Senopati Bantul sebagian besar menggunakan kontrasepsi hormonal sebanyak 29 responden (58,0\%).

\section{KEPUSTAKAAN}

1. Darayani, MD. (2011). Hubungan Umur Dengan Kejadian $\mathrm{Ca}$ Serviks di Laboratorium Patologi Anatomi Rsup Sanglah. Jurnal Dunia Kesehatan, Volume 2, Nomor 2.

2. Wijaya, D. (2010). Pembunuh Ganas Itu Bernama Kanker Serviks. Yogyakarta: Sinar Kejora.
3. Rasjidi, I. (2007). Vaksin Human Pappiloma Virus dan Eradikasi Kanker Mulut Rahim. Malang: Sagung Seto.

4. Rasjidi, I, G Soehartati, Aditama T. (2010). Epidemologi Kanker Pada Wanita. Jakarta: Sagung Seto.

5. Syaifuddin. (2012). Anatomi Fisiologi: Kurikulum Berbasis Kompetensi Untuk Keperawatan dan Kebidanan. Jakarta: EGC.

6. Soebachman A. (2011). Awas 7 Kanker Paling Mematikan. Yogyakarta: Syura Media Utama.

7. Manuaba dkk. (2010). Ilmu Kebidanan, Penyakit Kandungan dan KB Untuk Pendidikan Bidan. Ed 2. Jakarta : EGC

8. Purwadwiastuti. (2010). Kanker Serviks Pada Wanita. Alfabeta: Yogyakarta

9. Sulistyowati. (2012). Stadium Kanker Serviks Ditinjau Dari Usia Dan Paritas lbu Di Unit Rawat Jalan RSUD dr. Soegiri Kabupaten Lamongan. Vol. 3 , No.XIII, Des 2012.

10. Soekanto, S. (2006). Sosiologi Suatu Pengantar. Jakarta: PT.Raja Grafindo Persada

11. Harahap, E. Ruslan. (1997). Neoplasia Intra Epitel (NIS) Pada Serviks. Jakarta: UI Press.

12. Anna, M, dkk. (2009). Hubungan Kontrasepsi Pil dengan Tumor/Kanker Serviks di Indonesia. Majalah Kedokteran Indonesia, Volume: 59, Nomor:8 
13. Hidayati, W.B. (2001). Kanker Serviks Displasia Dapat Disembuhkan. Medika No 3 Tahun XXVIII;97.

14. American Cancer Society (2014). Cervical Cancer Prevention and Early Detection

15. Rasjid I (2009). Epidemiologi Kanker Serviks. Indonesian Journal of Cancer Vol. III, No. 3 Juli - September 2009

16. Lasut, E, dkk. (2015). Karakteristik Penderita Kanker Serviks Di Blu RSUP Prof. Dr. R. D. Kandou. Jurnal e-Clinic (eCl), Volume 3, Nomor 1, Januari-April 2015.

17. Nurwijaya, H dkk (2010) Cegah dan Deteksi Kanker Serviks. Jakarta. PT Gramedia. 